\title{
Nation Building in Zimbabwe and the Challenges of Ndebele Particularism
}

\author{
Sabelo J. Ndlovu-Gatsheni ${ }^{*}$
}

\section{Abstract}

This article deploys a politico-sociological historical analysis in the interrogation of the origins, tenacity and resilience of Ndebele particularism across pre-colonial, colonial and post-colonial epochs in Zimbabwe. While the issue of Ndebele particularism is currently overshadowed by the recent political and economic crisis that has seen Zimbabwe becoming a pariah state, it has continued to haunt both the project of nationalism that ended up unravelling along the fault-lines of Ndebele-Shona ethnicities and the post-colonial nation-building process that became marred by ethnic tensions and violence of the 1980s. In this article, Ndebele particularism is described at two main levels. Firstly, successive pre-colonial, colonial

* Dr Sabelo J. Ndlovu-Gatsheni is a Lecturer in African Studies at the Ferguson Centre for African and Asian Studies at the Open University, Milton Keynes in the United Kingdom and is also affiliated to the Department of History at the same university. His latest major publication is a book entitled The Ndebele Nation: Reflections on Hegemony, Memory and Historiography (SAVUSA/UNISA Press/Rozenberg Press, Amsterdam, 2008 in press). 
and post-colonial historical processes contributed to the construction and consolidation of Ndebele particularism. Secondly, this particularism is a product of coalescence of grievance and resentment to Shona triumphalism. The politico-sociological historical analysis is intertwined with a social constructivist perspective of understanding complex politics of identities in general. The discussion is taken up to the current reverberation of Ndebele particularistic politics on the internet including the creation of a virtual community known as United Mthwakazi Republic (UMR) that symbolises the desire for a restored pre-colonial Ndebele nation in the mould of Swaziland and Lesotho.

\section{Introduction}

Zimbabwe is one entity and shall never be separated into different entities. It's impossible. I am saying this because there are some people who are saying let's do what Lesotho did. There is no Lesotho here. There is one Zimbabwe and one Zimbabwe only. (Robert Mugabe, The Sunday Mail, 20 November 2005)

In May 2007 the former Governor and Resident Minister of Matabeleland North, Welshman Mabhena, wrote a letter to the British Ambassador in Harare as a 'Notice of intent to file an application for the review of the verdict of the Judicial Committee of the Privy Council in the Land Case Matabeleland on the 19th of 1918.' In the letter Mabhena (2007) wrote:

Your excellence you may be surprised to hear that I usually get lost when I come across people who mix up my country Matabeleland with Zimbabwe, because Zimbabwe is a former British Colony which was colonised in 1890 and granted independence on 18 April 1980. While my homeland Matabeleland is a territory which was an independent Kingdom until it was invaded by the British South Africa Company (BSA Co) on 4 November 1893, in defiance of the authority of Her Majesty Queen Victoria. Actually in terms of the Moffat Treaty of Peace and Unity of 11 February 1888 between Queen Victoria and 
King Lobengula, Britain and Matabeleland were allies, and due to our respect to our late King we have not renounced his vow.

Working within the auspices of the organisation known as Umhlahlo we Sizwe sika Mthwakazi dedicated to the restoration of an autonomous Kingdom of Matabeleland, Mabhena has progressed to file a legal case for review of the verdict of the judicial council of the Privy Council on the land case of Matabeleland on the $19^{\text {th }}$ of July 1918 by the British Government. What is of historical interest here is what is termed 'the thesis of the plight of the people of Matabeleland and its remedy' which outlines the constitutional history within which the people of Matabeleland were colonised and their sovereignty taken away. This is how the case is put forward:

The Respondent is the SOVEREIGN OF THE BRITISH CROWN a colonial power which granted the 'Royal Charter of Incorporation to the BSA Co.' and conferred it with all the powers of a government on all lands north of the Limpopo River. After the conquest of the Kingdom of Matabeleland on $4^{\text {th }}$ of November 1893 the Respondent did legalise the contraband deal of the BSA Co. pioneers, referred to as the 'Victoria Agreement of 14 August 1893' which was a scheme of displacing the people of Matabeleland and loot their cattle. I also submit that the Respondent went further to legalise the said contraband contract through the proclamation of the Matabeleland Order-in-Council on 19th of July $1894 \ldots$...The Respondent further ruled through the verdict of the Judicial Committee of the Privy Council in 1918 that: 'The Ndebele Sovereignty had been broken up and replaced by a new, better system as defined by the Matabeleland Order-in-Council of 1894'.

After the above judgement had usurped the Sovereignty of the Kingdom of Matabeleland through the said Order which replaced our statehood, the Respondent again through the 1923 Constitution of Southern Rhodesia, did confer the jurisdiction to the white supremacy regimes who were comprised of its descendants, the power of reigning over us through conquest, using the legal bases of the said Order, an act which 
continued to seriously prejudice our wellbeing for a duration which accrued to a total of 87 years under racial domination.

In 1980 again the Respondent went further to use the said Order as the legal basis of simultaneously decolonising Mashonaland with the status of an independent Republic of Zimbabwe, to which it consequently transferred the mandate of ruling us, in Matabeleland by conquest to black majority supremacy regime comprising of Shona tribe through 'The Constitution Order 1980 (S.I. 1980 of the United Kingdom) made 19 ${ }^{\text {th }}$ March 1980.' an act which has perpetuated tribal domination for 27 years bringing the duration of repression in Matabeleland to a total 114 years. $^{1}$

This case indicates the current embers in the politics of Ndebele particularism and the current drive for the restoration of an autonomous Ndebele nation separate from Zimbabwe. This article, therefore, interrogates the history behind the origins and resilience of Ndebele particularism - that makes it refuse to be swallowed by current territorial nationalism.

The Ndebele of Zimbabwe are variously described as a tribe, a clan and an ethnic group. But Ndebele novelists and culturalists, including active promoters of Ndebele particularism and advocates of the restoration of the pre-colonial Ndebele kingdom, prefer to use the term nation instead of tribe. ${ }^{2}$ The idea of the Ndebele as a distinctive nation inevitably threatens Shona hegemony that became triumphant in 1980 when the Zimbabwe African National - Patriotic Front (ZANU-PF), the former liberation movement that

1 An application for the review of the verdict of the judicial committee of the privy council in the land case of Matabeleland on the $19^{\text {th }}$ July 1918, with the view to ascertain its jurisdiction and to hear the demand of the people of Matabeleland who are praying for the revocation of the Matabeleland order-in-council of the $18^{\text {th }}$ July 1894 with the subsequent restoration of the kingdom of Matabeleland and the accompanying restitutions.

2 Among the leading promoters of Ndebele particularism and advocates of the restoration of the pre-colonial Ndebele kingdom is the former Governor of Matabeleland North, Welshman Mabhena, once a leading nationalist and resident minister under ZANU-PF and a radical Diaspora-based grouping known as Mthwakazi People's Congress (MPC). 
was dominated by the Shona-speaking people, came to power. As noted in the epigraph above, Robert Mugabe has ruled out as impossible the idea of the realisation of a restored and autonomous Ndebele nation in the mould of Swaziland and Lesotho. But throughout the liberation struggle, Ndebelespeaking people stuck with the Zimbabwe African People's Union (ZAPU). Whose support base and military wing were dominated by people from the south-western part of Zimbabwe. ${ }^{3}$ Ndebele historians like Pathisa Nyathi prefer to use the term $u M$ thwakazi for the Ndebele nation as it is done by the radical UK-based Mthwakazi People's Congress (MPC). ${ }^{4}$

This article starts by engaging with some theoretical and definitional issues including contested interpretations of who qualifies as a Ndebele in context of a society characterised by assimilation and incorporation of people from different ethnic groups into the Ndebele state. This process proceeds right from Mzilikazi Khumalo's (the founder of the Ndebele) migration from Nguniland to his final settlement on the south-western part of the Zimbabwean plateau in the late 1830s. The article engages with the historical processes that continued to reproduce Ndebele particularism right across the pre-colonial, colonial and post-colonial periods.

\section{Theoretical and interpretive framework}

A leading anthropologist, John Comaroff (1997), provided five theoretical propositions relevant to understand issues of ethnic identities in general. His first proposition was that ethnicity was constructed by specific historical forces which are simultaneously structural and cultural. He posits that ethnicity was never a unitary phenomenon because it described both a set of relations and a mode of consciousness that was ever changing. As a form of consciousness, ethnicity was one among many socially constructed

3 ZAPU recruited and mobilised its supporters mainly from Matabeleland since the time of the nationalist split of 1963 that gave birth to a Shona dominated ZANU that concentrated its recruitment in Mashonaland.

4 There is no clear definition of what uMthwakazi means. Some people think it is derived from $u M u t w a$ - a Ndebele name for the original inhabitants of Southern African known as the San. See Nyathi 1994, 1996 and 1999. 
phenomena that included totemism, each of which emerged within particular historical structures. Comaroff's third proposition was that while totemism emerged with the establishment of symmetrical relations between structurally similar social groupings which may or may not come to be integrated into one political community, ethnicity had its origins in the asymmetric incorporation of structurally dissimilar groupings into a single political economy. The fourth proposition was that while ethnicity was the product of a specific historical process, it tended to take on the 'natural' appearance of an autonomous force and a 'principle' capable of determining the course of social life. The final proposition was that ethnicity as an objectified 'principle' of collective consciousness of society, could be perpetuated by factors quite different from those that caused its emergence and could also develop a direct and independent impact on the context in which it arose (Comaroff 1997:69-85).

These are useful propositions that point to ethnicity as a socio-political constructed phenomenon emphasising that the process of construction is mediated and shaped by specifiable historical factors. Comaroff (1997:83) concludes:

The major problem, in both theoretical and empirical terms, it seems to me, is not to account for the genesis and persistence - or even the transformation - of ethnic consciousness and affiliation. Once ethnicity is understood to exist as a set of human relations, a product of specifiable historical forces and processes rather than a primordial 'given,' those issues become readily understandable.

This argument tallies with Leroy Vail (1989:xi) who stated that: 'If ethnic consciousness was a product of historical experience, then its creation and elaboration would be a proper subject of enquiry for historians.' With specific focus on the Ndebele, Bjorn Lindgren (2004:5-8) attempted to take into account what he termed 'historically formed specificity of ethnicity' and 'internal dynamics of ethnicity' in Matabeleland. He focused on clan names and castes in Matabeleland, arguing that Ndebele speakers use 
various clan names, origins, and 'castes' in a practice of naming and that these internal processes and 'practices break the category Ndebele into parts' (Lindgren 2004:5). Lindgren's interests were on smaller units of analysis like izibongo (surnames/clan names) as another avenue towards a more complex understanding of Ndebele ethnicity (Lindgren 2004). Lindgren's intervention ended with him trying to deploy the ephemeral izibongo (clan names/surnames) that need explanation in themselves as a scientific concept that could explain Ndebele identity. Ndebele izibongo are a very complex phenomenon on their own and have a complex history of their own for one to simplistically deploy as a concept to understand identity. For instance, in Matabeleland the isibongo Ndlovu is not signifying a single clan group. There are Ndlovu (Gatsheni) who are Nguni, Ndlovu (Gabula) who are Kalanga, Ndlovu (Mthombeni) who are Nguni and other Ndlovus with various ethnic origins. So one cannot use and take isibongo Ndlovu to mean a single clan and then quickly assign ethnic origin to the concept (Ndlovu-Gatsheni 2004). On top of this there were numerous people of Lozwi-Shona origin who used their own agency to translate their original Shona surnames into Ndlovu. The reality is that one finds numerous Ndlovus in Matabeleland and the Midlands regions sharing a common totem (elephant) but not tracing their descent from common clans or ethnic groups.

Totemic politics need explanation and cannot be deployed casually to enlighten debates on ethnicity in Matabeleland. Lindgren relied heavily on the works of white literate observers and early white writers who simplistically failed to go beyond the totem to the clan name in their definition of who was Ndebele and who was not (Hughes 1956; Child 1969). Ngwabi Bhebe, a historian, has shown that a number of people of Shona origin who were assimilated into the Ndebele state tended to Ndebele-lise their Shona surnames. Examples included Shiri becoming Tshili, Mhofu becoming Mpofu, Zhou becoming Ndlovu, Hungwe becoming Nyoni (Bhebhe 1979). Therefore, an approach to understanding Ndebele ethnicity based on izibongo rides roughshod over complex histories and complex processes of social engineering that took place in the Ndebele state. Lindgren ended up reviving the old fashioned idea of the 
Ndebele nation being divided into castes. This is how he put it (Lindgren 2004:13):

The isibongo places an individual within one of these categories of origin, and thereby within one of the three categories denoting 'caste': the Zansi, the Enhla and the Lozwi (or Holi).

The discourse of castes just like that of izibongo ignores historical factors and social fluidities within the Ndebele state. For instance, the term Zansi literally meant the South in geographic sense while Enhla literally means the North. It also denotes direction. But Lozwi is a form of ethnic identity of a branch of Shona people who belonged to the Rozvi state that dominated the south-western part of the Zimbabwean plateau prior to the arrival of the Ndebele. This means that at one level people in the Ndebele state were categorised according to where they came from with the abeZansi (those from the South) forming an aristocratic grouping, the abeNhla (those from the North) constituting a second layer of grouping, and those assimilated from the Rozvi state forming the Holi grouping. ${ }^{5}$

Terence Ranger (1994b:10) defined identity in Matabeleland at two levels. The first was what he termed the 'generous' and 'inclusive' and the second was what he described as the 'narrow' and xenophobic. The formation and consolidation of the Ndebele state was predicated on the generous and inclusive assimilationist policy where Ndebele language became a common signifier of identity (Ndlovu-Gatsheni 2009). The Ndebele were active in defining and articulating their identity in positive terms of a strong nation. And their neighbouring Shona communities also engaged in defining the Ndebele as a tribe that only expanded through forcible assimilation of captured Shona people, the majority of whom were given Ndebele-oriented animal totems as surnames. What Ranger termed the narrow and xenophobic conception of Ndebele identity was also promoted by the Shona groups

5 It is not yet well established by historians what the term Holi/Hole literally meant. Some argue that it was derived from amaholingubo (those with long dresses touching the ground), a reference to the style of clothes put on by the Rozvi. 
for counter-hegemonic purposes. In this scheme of things, the Ndebele were reduced to Ngunis who were identifiable through such surnames as Khumalo, Mkwananzi, Gumede, Mafu, Gatsheni and Mathema. ${ }^{6}$

So far there are many versions of Ndebele identity that have mushroomed in recent years. The most narrow and ill-informed of them all is that one that reduces being Ndebele to being members of the Khumalo clan that constituted itself as the ruling elite under Mzilikazi and Lobengula Khumalo. This is a clannish definition that fails to take into account the complex processes of nation building evolved by Mzilikazi who continually added new groups into the lower echelons of the original Khumalo clan. The second version is one that defined Ndebele-ness linguistically - as comprising any one who spoke Ndebele language as a mother tongue. Then there is the regional-local definition that defines a Ndebele as any person residing in Matabeleland or the Midlands regions of Zimbabwe. This I will call the regional-geographic definition of being Ndebele. To those with a hegemonic Ndebele agenda, being a Ndebele means a conglomeration of all those people whose ancestors were assimilated into the Ndebele state, be they of Nguni, Sotho, Shona, Kalanga, Tonga, Tswana, Venda or Lozwi extraction. This historical-pluralistic-hegemonic definition of being Ndebele celebrates the Ndebele nation as a pre-colonial form of a rainbow nation. The most recent definition was concocted during the post-colonial era and in the midst of violence that engulfed Matabeleland and the Midlands regions of Zimbabwe in the period 1980-1987. During this period being Ndebele was limited to being loyal to Joshua Nkomo and PF-ZAPU, the former liberation movement that became an opposition after 1980 (Sibanda 2005). This political definition had the immediate impact of uniting all those who were brutalised by the Fifth Brigade, not only as a dissident community as ZANU-PF and Robert Mugabe defined them, but also as a victimised and unwanted community that had to look for a state of their own (Msindo 2004). This definition took the form of post-colonial re-tribalisation and provincialisation of Ndebele identity that was initiated by the state in the period 1980-1987. Its message was very simple: 'ZAPU is connected with dissidents and ZAPU is Ndebele

6 This is an attempt to reduce Ndebele identity to barely a handful of clans. 
therefore the Ndebele are dissidents' (Abrams 2006:60). As put by Enos Nkala, Nkomo was then the modern Ndebele king (BBC 1983).

Since 1980, the Ndebele identity continued to undergo a continuous process of minoritisation as Shona identity picked the agenda of hegemonic triumphalism. Finex Ndhlovu, a language specialist based in Australia, argued that the notion of ethnic minorities is a highly contested subject that cannot be fully explained in terms of demographic facts alone as it is indexically linked to struggles over socio-political power, cultural domination and control (Ndhlovu 2006:1). He explored how discursive practices underwriting the hegemony of dominating ethnic groups like the Shona, the use of languages as markers of ethnic and national identity, as well as the appropriation and abuse of the terminology such as 'minority' and 'majority' are deployed in Zimbabwe in pursuit of exclusionary political agendas (Ndhlovu 2006:1).

One can define the Ndebele as an ethnic group as well as a nation. But Stephen Barbour (2001:7) tried to differentiate an ethnic group from a nation in this way:

Unlike a nation, an ethnic group need not occupy a territory. Also, unlike a nation, its 'common myths and historical memories' may be more plausible; since ethnic groups may be much smaller than modern nations... And, rather than a 'mass, public culture' uniting very disparate elements, there may be high level of shared cultural norms; and there is usually a shared language.

All these complex definitions cannot make sense outside a properly nuanced interrogation of specific historical processes that continued to enact, produce and reproduce Ndebele particularism. 


\section{Historical interpretation of the construction of Ndebele Identity}

Ndebele particularistic ethnic identity has a pre-colonial, colonial and postcolonial origin. Its origins are lodged within the complex nation-building project initiated by King Mzilikazi Khumalo and taken further by his son and successor King Lobengula Khumalo. The Rhodesia settler-colonial state was not an innocent bystander in this process and the Shona-dominated post-colonial Zimbabwean state also shared in this process. ${ }^{7}$ What is not in doubt is that Ndebele identity is a product of complex constructivist processes that span pre-colonial, colonial and post-colonial epochs. ${ }^{8} \mathrm{~A}$ historically informed, careful and nuanced analysis of the evolution of Ndebele particularism should take into account such concrete historical factors as the Mfecane Revolution and Nguni-Sotho nation building strategies of the 1820s, as well as the role of colonialists and African nationalists in pushing the evolution of the country towards self-determination along bifurcated ethnic lines. Post-independence events like the connection of Shona triumphalism with Gukurahundi atrocities; the limits of the Unity Accord, the death of Joshua Nkomo and the current Zimbabwe crisis with its displacement of many people and the resultant formation of exile-based diasporic communities obsessed with identity politics need to be analysed and factored into the understanding of Ndebele identity politics.

It was the superior art of nation building displayed by Mzilikazi Khumalo that led the historian John D. Omer-Cooper (1966:8) to present the Mfecane as a positive process of political change and a 'revolution in Bantu Africa'. Despite the vigorous revisions of the Mfecane by Julian Cobbing in the 1980s and 1990s, and his attempt to 'jettison' the Mfecane from Southern African History, no one has disputed that this revolution was marked by creative statecraft that led to the emergence of such new political and social formations

7 Terence Ranger, who previously emphasised the colonial 'inventedness' of Ndebele identity, later accepted the pre-colonial 'inventedness' of Ndebele identity in his Voices from the Rocks: Nature, Culture and History in the Matopos Hills of Zimbabwe (Ranger 1999:99ff).

8 See Ranger 1985, 1993 and 1994a. 
such as the Ndebele in the highveld of South Africa (Cobbing 1988). ${ }^{9}$ The process unfolded in terms of how a small Khumalo clan expanded into a nation and how a small Khumalo ruling elite managed to broadcast its power over people of different ethnic groups. Mzilikazi employed such strategies as raiding, conquest, assimilation and the incorporation of individuals, groups and communities. It included inculcating Ndebele values and language over people of different ethnic groups (Cobbing 1976). By the time of Ndebele permanent settlement on the south-western part of the Zimbabwean plateau after 1840, what had started as a small Khumalo clan had snowballed over time into a heterogeneous nation consisting of different groups. On how the Ndebele won a sizeable number of Sotho and Tswana communities into their nascent state, Margaret Kinsman argued that the presence of the Ndebele on the western highveld from 1826 to 1838 introduced a period of ambiguous peace rather than devastation. The Ndebele managed to push out the Griqua, Kora and other brigands that subsisted on raiding the Sotho and the Tswana. This atmosphere attracted some of these communities to join the Ndebele on their own volition. ${ }^{10}$

It was the Boer Trekkers, trekking from the Cape Colony in what became known as the Great Trek, who used firearms in their constant attacks on the Ndebele and eventually forced Mzilikazi to migrate to the Zimbabwean plateau (Pretorius \& Kruger 1937; Tylden 1953). On reaching the Zimbabwean plateau, the process of nation building continued in the form of conquest, assimilation and incorporation of Lozwi, Kalanga, Birwa, Tonga, Nyubi, Venda, and Suthu inhabitants of the south-west. It was those people of the south-western part of the Zimbabwe plateau who constituted the third

9 See also extended debates on the Mfecane in Hamilton 1995.

10 See Kinsman 1995, where details are given on how some Sotho and Tswana communities voluntarily joined the Ndebele and how some were attached and forcibly incorporated into the Ndebele state. 
segment in the Ndebele state known as abaLozwi or amaHole. ${ }^{11}$ Lindgren (2005) correctly noticed a basic feature of Ndebele ethnicity: that it was built on multiple origins that were ordered in a hierarchy of belonging. A Ndebele may be of Nguni, Sotho, Tswana, Khalanga, Venda, Tonga and/or Shona origin. Commenting on this arrangement and organisation of the Ndebele state, Sithole wrote, 'It would seem then, that the social system among the Ndebele was a 'porous' or 'flexible' rather than rigid caste system' (Sithole 1995:130). The uniting factor was the language known as IsiNdebele.

The best way to understand Ndebele ethnic identity is as a socially constructed phenomenon, not as a fixed primordial identity. It must be understood as the protean outcome of the continuous and generally conflictridden interaction of political, economic and cultural forces both external and internal to developing ethnic communities (Berman 1998:310). Jocelyn Alexander, JoAnn McGregor and Terence Ranger in their book Violence and Memory: One Hundred Years in the 'Dark Forests' of Matabeleland (Alexander et al 2000) captured how violence and its memory shaped the history and identity of the Ndebele people of Zimbabwe. They explored in detail how the interconnections of nationalism, ethnicity, religion, Ndebele resistance against colonial forces as well as the assaults on the Ndebele by the postcolonial forces contributed to the reinforcement of Ndebele identity. What has not been explored is the issue of how the Ndebele continued to promote their 'particularism' within the colonial state and even after the achievement of independence. This particularism refers to the rendition of a separate Ndebele history which is different from the Shona historical experiences, the attempts to revive Ndebele kingship, and the continual formation of Ndebele particularistic organisations up to the mass nationalism phase of Zimbabwean history.

11 AbaLozwi were part of the Rozvi state ruled over by the Mambos (rulers). This Rozvi state was found by the Ndebele already tottering and breaking into smaller chieftaincies. As such the Rozvi people were not able to offer united resistance to the Ndebele invaders from the South. The Ndebele assumed that all the people of the South-west were under Rozvi rule before they came hence they labelled those assimilated into the Ndebele state on the Zimbabwean plateau amaLozwi. 


\section{Colonialism, nationalism and Ndebele particularism}

The colonialists did not 'invent' Ndebele ethnic identity; they 'reconstructed' it for colonial purposes. By the time of colonial rule, the Ndebele state had existed as a centralised political reality in the south-western part of the Zimbabwean plateau with people who were conscious of being Ndebele and who spoke IsiNdebele as their national language (Cobbing 1976; NdlovuGatsheni 2004). The Ndebele existed as an independent nation up to 1893 when King Lobengula was violently removed from power by the British colonialists. While Mashonaland was occupied in 1890 by the Pioneer Column that culminated in the raising of the Union Jack Flag in Fort Salisbury in September 1890, the Ndebele state remained independent for the next four years. Colonial rule was extended from Mashonaland to the Ndebele state after the Anglo-Ndebele War of 1893 where the Ndebele forces tried to resist the invasion of their state by Cecil John Rhodes's imperialist forces (Glass 1968). This led the historian Arthur Keppel-Jones (1983:8-11) to argue that Mashonaland was 'occupied' and Matabeleland was 'conquered.' The heroic charge of the Ndebele against the colonial forces' encampments at the Shangani and Mbembesi Rivers was inscribed into Ndebele national memory. The disappearance of the king was also captured as a Ndebele national memory. A common Ndebele song regarding these events went like this:

Kudala kwakunganje

Umhhlab' uyaphenduka

Kwakubus' uMambo lo Mzilikazi.

Sawela uTshangane,

Saguqa ngamadolo

Inkosi uLobengula yasinyamalala. ${ }^{12}$

[The world is changing; things were not like this in the olden days.

The reigning kings were Mambo and Mzilikazi.

But when we fought at Tshangane River,

12 This popular song is a summary of how the Ndebele perceived the conquest of their state and how their lives were changing. It is a song that clearly indicates the Ndebele awareness of changing circumstances and what it meant to their nationhood. 
And we fell on our knees,

King Lobengula then disappeared.]

This song encapsulated how the Ndebele as a nation understood the impact of colonial rule and the changing circumstances brought about by colonialism, particularly the disappearance of black kings and their replacement by white rulers. Despite the disappearance of their king in 1893, the Ndebele were able to use their remaining institutions to rise against the colonising chartered British South Africa Company in March 1896. ${ }^{13}$ All this indicates the resilience and cohesiveness of the Ndebele nation and its level of political consciousness together with their desire to restore their sovereignty (Cobbing 1977; Beech 1986; Ranger 1967). The surrender of the Ndebele in 1896 was facilitated through negotiations (Indaba) at Matopos Hills where Cecil John Rhodes made some promises to the Ndebele which included giving them seeds for farming and the return of some originally looted cattle to the Ndebele chiefs (Ranger 1999). This means that the Ndebele even emerged from the Uprising of 1896 as a cohesive nation. This lasted up until the time of the massive evictions of the Ndebele from areas around Bulawayo to far away areas, which opened the way for white commercial farming in the 1920s and after the Second World War (Ndlovu-Gatsheni 2007).

Since the colonial conquest, the Ndebele have not given up the dream of re-establishing themselves as a nation with a new king as its head. Terence Ranger, in The African Voice in Southern Rhodesia, provides details on how in the period 1898-1930 the Ndebele formed what he described as protest movements that were partly looking towards accommodation with the structures of the colonial states and partly campaigning for a separate homeland (Ranger 1970). The main voice fighting for a separate Ndebele homeland was Lobengula's son Nyamande Khumalo who played a leading role in the formation of the National Home Movement which was succeeded by the Matabele Home Society after his death (Ndlovu-Gatsheni 2007:183-184). In recent years Ray S. Roberts has interrogated the history of

13 The issue of the disappearance of the king is discussed in Lindgren 2002a. See also Lindgren $2002 \mathrm{~b}$. 
Khumalo royal family focusing on the sons of King Lobengula, the roles they played in Ndebele protest movements during the colonial period and how the colonial state treated them. Though he tries to critique Ranger's concept of the 'African voice' by arguing that the story of Lobengula's other sons (with the exception of Nyamanda), particularly Nguboyenja Khumalo, was not of great importance politically, his articulation of Matabeleland politics in the light of Lobengula's family indicates how the Ndebele still aspired to be a nation, how they were conscious of their identity and how they still looked to the sons of Lobengula as leaders of the Ndebele nation (Roberts 1984; Roberts 2005). For instance, Rhodes Lobengula Khumalo, one of the sons of Lobengula, was active in the Matabele Home Society, introduced football and boxing as sports to Bulawayo and continued the fight to protect Ndebele interests (Roberts 2005:38). While the Ndebele associations, from the National Home Movement, the Matabele Home Society to the Mzilikazi Family Association, might have somewhat chequered histories, they indicated the level of consciousness of the Ndebele and their attempt to maintain a particularistic identity within the confines of the colonial state. Enocent Msindo analysed how Ndebele attacked the Shona working and residing in Bulawayo in 1929 as part of Ndebele claims to Bulawayo as their city even though it was now run by the colonial regime. Despite being colonised, the Ndebele still viewed Bulawayo as their city, deriving ammunition from its pre-colonial history as isigodlo (the capital city) of the Ndebele state. Msindo (2006:433) made this point clear when he wrote that:

This fossilisation, in a settlement previously a Ndebele pre-colonial headquarters, of 'foreign' languages, different ethnicities and modes of behaviour, explains why it took a heavy and protracted struggle for the Ndebele and other inhabitants of Matabeleland to 'regain' Bulawayo.

Throughout the colonial period up to the time of the rise of the mass nationalist movements, the Ndebele had tried very hard to maintain a certain level of particularism. The colonial state reinforced this development of particularism by dividing the country into ethnic names like Matabeleland, 
Mashonaland and Manicaland. Bruce J. Berman (1998:315) commented on this colonial development in this way:

Each administrative unit ideally contained a single culturally and linguistically homogeneous 'tribe' in which people continued to live within the indigenous institutions and were subject to 'tribal discipline' through local structures of authority. The imperatives of control thus also constrained the transformation of African societies and indeed, made what the colonial state understood to be the local institutions of tribe and kinship into grassroots foundations of colonial domination, as well as a means by which it could derive a degree of legitimacy from association with 'traditional' social forces. ${ }^{14}$

Ndebele particularism continued to reverberate within the colonial state to the extent that the Matabele Home Society successfully lobbied and agitated for name-change of Rufaro Township into Njube Township (Roberts 2005). Rufaro was a Shona name for a township at the centre of Bulawayo. Njube was one of the sons of Lobengula. This change was owing to the urban work of the Matabele Home Society. Roberts concluded that 'the Home Society, the Mzilikazi Family Association, and indeed the Khumalo as traditional leaders outside the colonial order, played their part, holding the people of western Zimbabwe together, as a nation defined by culture rather than as nationalists defined by politics' (Roberts 2005:37).

Masipula Sithole, who studied Zimbabwean nationalism from the perspective of ethnicity, noted that at the formation of the first mass nationalist organisation, the Southern Rhodesia African National Congress (SRANC) in 1957, the Ndebele-Shona axis emerged, manifesting itself in the words exchanged at the founding congress as well as in the structure established to lead the party. Conscious effort was made to achieve ethnic or regional balance between the Ndebele and the Shona (Sithole 1995:132). ${ }^{15}$ By 1963, a major ethnic rift hit the nationalist politics with the Zimbabwe African

14 See also Ranger 1985.

15 See also Sithole 1999. 
People's Union (ZAPU) splitting along ethnic lines into the Zimbabwe African National Union (ZANU) that was Shona dominated and ZAPU that became Ndebele dominated (Nkomo 1984). ${ }^{16}$ Since that time the history of ZAPU and ZANU have become a tale of ethnic politics and tribalism, bringing more division than unity to the Ndebele and the Shona.

The Zimbabwean nationalists carried the burden of trying to balance the ethnic factor in their respective political organisations in a bid to gain national support and in a bid to manage ethnic differences. Within ZANU the burden was how to balance and manage the equally volatile issue of intraShona ethnicities involving Karanga, Zezuru, Manyika and Korekore groups. ZAPU had to balance Ndebele-Kalanga-Shona composition and Muzorewa and Sithole were engaged in similar processes within their respective organisations. Chief Khayisa Ndiweni of Ntabazinduna in Matabeleland even went to the extent of forming the United National Federal Party (UNFP) that advocated for open power sharing 'between the two major communities in the country' (Sithole 1986:79-84).

\section{The recent recurrences of Ndebele particularism}

The first crisis that hit the post-colonial nation-building project had to do with ethnicity and integration of military forces. A crisis which began in the ranks of the military, involving open exchange of fire between the triumphant and Shona-dominant ZANLA and the Ndebele-dominated ZIPRA in Connemara (Gweru) and Entumbane (Bulawayo), which ignited a reign of state terror in Matabeleland and the Midlands region in the period 19801987. The reign of terror that became known as the Gukurahundicampaign was ostensibly meant to seek and destroy some ex-ZIPRA combatants who had defected from the Zimbabwe National Army (ZNA) to embark on a life of dissidence. But as noted by Bhebe the violence was somehow an inevitable consequence of the way nationalism had evolved and how the nationalist armies had been formed. This is how he puts it:

16 Where Nkomo blames Leopold Takawira for fomenting the split on tribal lines. 
It is not unreasonable for readers to ask how such close allies [as ZANU and ZAPU] could be involved in a civil war that saw many lives being lost in Matabeleland. On the other hand, to us such a question would only show that the reader has not read this book with attention. For the book has shown how factional conflict in Zimbabwe, or among Zimbabweans, is quite close to the surface. It does not matter whether people belong to the same party...The situation is worse when people belong to different political parties. The reader saw how ZAPU and ZANU followers started killing each other when they were dumped together at Mboroma by the Zambian authorities. The ZIPA experiment in Mozambique collapsed for just that same reason. In Libya, ZAPU and ZANU were put in the same training camps and they killed each other. The reason was very simple. These young men and women were trained to hate each other by their leaders, who wanted to justify the separate existence of their parties. Each party had its own Commissariat Department, whose task was to teach recruits the history of the party, how the party was different from each other, who the leaders were and how they were different from the less revolutionary or sell-out leaders of the rival party. Thus, the cadres were brought up to hate (Bhebe 2004a:256).

The post-colonial period was crucial in the process of furthering Ndebele particularism by the state's use of violence. The ethnically inspired clashes between ZIPRA and ZANLA in the Assembly Points, the running away of some ex-ZIPRA combatants back to the bush, the exploitation of the antagonistic situation by apartheid South Africa via Super ZAPU, and the 'discovery' of arms caches in PF-ZAPU owned farms around Bulawayo, gave the Shona-led government a pretext to use state power to crush PF-ZAPU once and for all, demonstrate to the Ndebele who was in power and widen ZANU-PF control into the south-western part of the country. According to Brian Eric Abrams (2006:24), ZANU-PF and the state 'developed a clear message, sharp media campaign and a multi-layered military response to achieve its highly focused political goals.' The violence was in reality an indication of how Ndebele particularism could not easily blend with a Shona 
imagined nation and Shona triumphalism. This was indicated by the fact that while the policy of national reconciliation (uniting whites and blacks) endured until 2000, the national policy of unity (uniting blacks) collapsed in 1982 and was followed by ferocious civil war.

As clearly detailed in the Catholic Commission for Justice and Peace (CCJP) and the Legal Resources Foundation (LRF)'s Report, Breaking the Silence: Building True Peace: A Report on the Disturbances in Matabeleland and the Midlands, 1980-1989, the military operation that was orchestrated through deployment of the Fifth Brigade (Gukurahundi) became a bizarre combination of random killing of every Ndebele-speaker, hunting and killing of every PF-ZAPU supporter, raping of Ndebele women and girls, as well as abduction, torture, politicisation and attempts at forcing every Ndebelespeaker to switch to the Shona language and then support ZANU-PF (CCJP \& LRF 1997). ${ }^{17}$ Bhebe (2004b:15) had this to say about the roots of this violence:

Moreover, when people discuss our nationalist historiography they want to pour their worst venom on ZANU-PF and even forget the inevitability of our post-colonial civil war. Perhaps what was not inevitable were its excesses. But frankly, considering the way we had built our guerrilla armies, I again doubt whether a ZIPRA dominated army would have fought such a civil war in Mashonaland any different from the way ZANLA dominated Zimbabwe National Army fought the civil war in the Midlands and Matabeleland. I am aware of the destructive and brutal role of the Korean trained Gukurahundi, but are we certain that if we, as ZAPU, had won the elections, we would not have had our friends to train our own military units to destroy or tame former ZANLA forces. Rivalry between ZAPU and ZANU was simply too much and uncontrollable and only those who were on the periphery of our struggle deserve to misunderstand our post-colonial conflicts.

17 See also Alexander 1998:151-182 and Yap 2001. 
To some extent we accept the notion of the inevitability of a violent postcolonial civil war pitting the former liberation movements and their former armies against each other. But there is need to posit that the inevitability of violence was underwritten by incompatibilities of Ndebele and Shona particularities. The violence was in a way symptomatic of the failure of a smooth blending of major ethnicities into a new national identity called Zimbabwe. The net effect of this was that violence was the only invitation card by which the Ndebele were invited into a Shona-imagined nation. Matabeleland had to be conquered and forced into part of Zimbabwe. That was the essence of the violence of the 1980s. PF-ZAPU, ZIPRA and Joshua Nkomo only happened to be mistaken for symbols of Ndebele particularism. It is within this context that the impact of that violence has to be understood, particularly its role in the re-packaging of post-Gukurahundi politics in Matabeleland. The proclamation of uMhlahlo we Sizwe sika Mthwakazi has summarised the forms of oppression emanating from Shona triumphalism in this way:

a. Marginalisation of the elected MPs of Matabeleland

b. Instituting the reign of terror in Matabeleland

c. Perpetrating ethnic cleansing against the people of Matabeleland

d. Translocation of the economic resources of Matabeleland to Mashonaland

e. Reserving key jobs for Shona people in Matabeleland

f. Depriving the people of Matabeleland of education opportunities

g. Retarding the cultural identity of the inter-cultural society of Matabeleland 18

This list encapsulates the core reasons for Ndebele resentment of the postcolonial nation, as a Shona nation and post-colonial state serving Shona interests at the expense of Ndebele. The openly ethnic nature of the violence did not help matters as it made the Ndebele to be even more aware of their differences with the Shona. Lindgren (2005:158) noted that 'people in Matabeleland responded by accusing Mugabe, the government and the 'Shona' in general of killing the Ndebele'. Besides the Fifth Brigade atrocities instilling fear in Matabeleland and the Midlands, it heightened the victims'

18 The proclamation of uMhlahlo we Sizwe sika Mthwakazi. 
awareness of being Ndebele and a sense of not being part of Zimbabwe. ${ }^{19}$ The Unity Accord that was signed between PF-ZAPU and ZANU-PF on 22 December 1987 was nothing less than a surrender document where the PF-ZAPU politicians threw in the towel and allowed PF-ZAPU to be swallowed by ZANU-PF.20 The bitterness and the memory of having lost family members, relatives and friends did not go away with the Unity Accord (Ndlovu-Gatsheni 2003).

Gukurahundi violence provoked radical Ndebele cultural nationalism as well as radical Ndebele politics that sometimes contested the whole idea of a unitary Zimbabwe state. This spirit manifested itself more openly in the formation of such radical Ndebele pressure groups as Vukani Mahlabezulu, Imbovane Yamahlabezulu, ZAPU 2000, as well as Mthwakazi Action Group on Genocide and Ethnic Cleansing in Matabeleland and Midlands and Mthwakazi People's Congress (MPC). ${ }^{21}$ The first organisation focused more on revival of particularistic features of Ndebele culture and its main proponent was a novelist and academic, Mthandazo Ndema Ngwenya, who lost his life in a car accident on the Bulawayo-Harare Road. The second one concentrated on the issue of making those who perpetrated atrocities in the 1980s accountable for their sins. Such political figures as Enos Nkala and others, like Joseph Msika, were invited to explain to the people as to who gave the instructions for atrocities that affected the Ndebele of Matabeleland and the Midlands regions. The third one was a belated attempt to revive ZAPU following the death of Joshua Nkomo in July 1999. Its focus was repudiation of the Unity Accord which was interpreted as a surrender document that did not benefit the ordinary people of Matabeleland who suffered the consequences of ethnic violence. It accused the former ZAPU elite of selling

19 In 2002, I carried out in-depth oral interviews in Bulawayo and Gweru about the Ndebele perceptions of the military and the results indicated that to the Ndebele, the military is a Shona-manned institution organised to kill those who are not Shona.

20 For details on the Unity Accord see Chiwewe 1989.

21 These organisations came into being in the wake of the swallowing up of PF-ZAPU by ZANU-PF in 1987 and they tried to continue the work of such other earlier organisations as Ndebele National Movement, Matabele Home Society and Mzilikazi Family Association that were decentred by the rise of mass nationalism. 
out the people of Matabeleland for personal interests. The last two were a Diaspora phenomenon and they seek the establishment of an autonomous United Mthwakazi Republic (UMR) as the only way for the Ndebele people to realise self-determination. ${ }^{22}$ Umhlahlo we Sizwe sika Mthwakazi must be understood within this politics and it defines itself in these terms:

Umhlahlo we Sizwe sika Mthwakazi is being proclaimed as a freedom front to eradicate the oppression and suppression of the people of Matabeleland along tribal lines. Umhlahlo shall not be a political party and has no programme of contesting elections because of the people of Matabeleland have no freedom to govern themselves. Instead Umhlahlo is a community umbrella of the Inter-Cultural Society of Matabeleland which is committed to the principles of the Universal Declaration of Human Rights. It is non-violent community rooted umbrella of all the suppressed people regardless of partisan, ethnicity, creed, gender, class or age. Its membership is free to individuals, groups, institutions and associations who adhere to the principles of justice and humanitarianism. ${ }^{23}$

The processes of Matabeleland politics are complex. As represented by Umhlahlo we Sizwe sika Mthwakazi and other discreet groupings, the politics is both anti-colonial and anti-Shona domination. The young generation of political activists in Matabeleland are very sceptical of territorial nationalism as represented by ZANU-PF. The common perception is that ZANU-PF is a tribal party that survives on tribalism. This position was recently put forward by one regular columnist for New Zimbabwe.com (Mabhena 2006):

ZANU-PF is a party that is founded on splitting Zimbabwe into tribal groupings, i.e. Shona and Ndebele, whereby Shonas must provide national leadership. ZANU-PF, usually referred to as 'The Party' has always had in their leadership deck Shonas taking up key leadership

22 The emergence of these organisations may also be interpreted within the broader perspective of the rise of civil society at the end of the Cold War.

23 The proclamation of uMhlahlo we Sizwe sika Mthwakazi. 
positions with a lacing of Ndebele apologists making up the leadership elite numbers. The party had to enlist the services of Ndebele apologists to paint a picture of a government of national unity following the inconsequential 'Unity Accord' signed in December 1987. The Ndebele apologists were to behave like gagged guests at this party - 'make no key decisions and above all don't raise questions about the development of the other half of the country.

The Matabeleland problem continues to impinge on and to pulsate within national politics and its salience led Khanyisela Moyo (2006) to state: 'In my opinion, the Matabele question is critical and cannot be cursorily thrust aside. It should be subjected to an intellectual and candid debate. Currently, the embers of the Matabeleland problem are burning more in the Diaspora than in Zimbabwe due to the Zimbabwe crisis that unfolded in 1997 sending millions of people into the Diaspora. The dimensions of the Matabeleland problem in the Diaspora have included Ndebele-speakers linking up via the internet and continuation of the project of fighting for recognition of Ndebele particularism. Already there exists an imagined autonomous United Mthwakazi Republic (UMR), complete with its own national flag and other ritualistic trappings of a state, if not a nation-state as a virtual community on the internet. A separate history is claimed together with appropriation of Joshua Nkomo, ZAPU and ZIPRA as the property and heritage of the Ndebele. What is at play is serious contestation of Shona triumphalism and hegemony. Mthwakazi proponents have openly declared that:

For our part, for our present generation, this Zimbabwe, and any attempts to maintain it in any guise in future as a state that includes uMthwakazi, is as false as it is silly. It is only part of the grand illusion of the whole Zimbabwe project created in 1980 ... What we have is their Zimbabwe, of Shonas, and a fledging state for uMthwakazi which we have called UMR. (Mthwakazi 2006)

These radical separatist politics co-exists with an equally strong drive by some politicians from Matabeleland and the Midlands regions to close ranks 
with such political organisations as the Movement for Democratic Change (MDC), to fight for what they term a 'New Zimbabwe'. These politicians still believe in the power of territorial nationalism and they define the problem as an issue of governance rather than ethnicity. Added to this constituency are the old guard ZAPU nationalists who have continued their membership in ZANU-PF despite being pushed to peripheral positions within the party and the government. All this indicates the depth of the complexities of Matabeleland politics and the lack of consensus within the region on the best way forward.

\section{Conclusion}

What is beyond doubt is that what I have termed Ndebele particularism is a complex phenomenon that cannot be ignored in the imaginations of a post-crisis Zimbabwe. It is at the root of the problem of how two nations (Shona and Ndebele) with different pre-colonial histories and memories can be invited into one centralised state that masquerades as a state adhering to the Shona worldview. Ndebele particularism does not fit easily into this imagined nation and the state where Ndebele experiences, histories and heroes are subordinated to triumphant and hegemonic Shona history, if not completely ignored. The way the post-colonial state was abused by ZANU-PF in its drive to violently destroy Ndebele particularism set in motion the current Matabeleland politics of alienation, resentment and grievance that are combining to fuel the desire for a restoration of the pre-colonial Ndebele state. There is pervasive fear in Matabeleland that without a state of their own the Ndebele remain in danger of a repetition of Gukurahundi. The Ndebele people have come to realise that states are used as vehicles to suppress unwanted communities and hence their drive for their own state that will cater for their own national interests.

\section{Sources}

Abrams, Brian Eric 2006. Strategy of Domination: ZANU-PF's Use of Ethnic Conflict as a Means of Maintaining Political Control in Zimbabwe, 1982-2006. Unpublished M.A. thesis, Tufts University. 


\section{Sabelo J. Ndlovu-Gatsheni}

Alexander, Jocelyn 1998. Dissident Perspectives on Zimbabwe's Post-Independence War. Africa 86 (2), 151-182.

Alexander, Jocelyn; McGregor, JoAnn \& Ranger, Terence 2000. Violence and Memory: One Hundred Years in the 'Dark Forests' of Matabeleland. Harare: Weaver Press.

Barbour, Stephen 2001. Introduction: Nationalism, Language, Europe, in Barbour, Stephen \& Carmichael, Cathie (eds), Language and Nationalism in Europe. Oxford: Oxford University Press.

BBC (British Broadcasting Corporation) 1983. Zimbabwe in Brief: Nkala's Call for Liquidation of ZAPU. BBC Summary of World Broadcasts, 7 March 1983.

Beech, David N. 1986. War and Politics in Zimbabwe, 1840-1900. Gweru: Mambo Press.

Berman, Bruce J. 1998. Ethnicity, Patronage and the African State: The Politics of Uncivil Nationalism. African Affairs 97.

Bhebe, Ngwabi 1979. Christianity and Traditional Religion in Western Zimbabwe. London: Longman.

Bhebe, Ngwabi 2004a. Simon Vengayi Muzenda and the Struggle for and Liberation of Zimbabwe. Gweru: Mambo Press.

Bhebe, Ngwabi 2004b. The Golden Age of Zimbabwe's Historiography and Its Decline from 1967 to the Present. The Dyke: The Journal of Midlands State University 1 (1).

CCJP (Catholic Commission for Justice and Peace) \& LRF (Legal Resources Foundation) 1997. Breaking the Silence, Building True Peace: A Report on the Disturbances in Matabeleland and the Midlands, 1980-1989. Harare: CCJP \& LRF.

Child, Harold 1969. The History of the AmaNdebele. Salisbury: Ministry of Internal Affairs.

Chiwewe, Willard Anasi 1989. Unity Negotiations, in Banana, Canaan S. (ed), Zimbabwe, 1890-1990: Turmoil and Tenacity. Harare: The College Press.

Cobbing, Julian 1976. The Ndebele under the Khumalos, 1820-1896. Unpublished Ph.D. thesis, University of Lancaster.

Cobbing, Julian 1977. The Absent Priesthood: Another Look at the Rhodesian Risings of 1896-7. Journal of African History xviii (1).

Cobbing, Julian 1988. The Mfecane as Alibi: Thoughts on Dithakong and Mbolopo. Journal of African History 29, 487-519.

Comaroff, John L. 1997. Of Totemism and Ethnicity: Consciousness, Practice and the Signs of Inequality, in Grinker, Roy Richard \& Steiner, Christopher B. (eds), Perspectives on Africa: A Reader in Culture, History, and Representation. Oxford: Blackwell Publishing.

Glass, S. 1968. The Matabele War. London: Longmans.

Hamilton, Carolyn (ed) 1995. The Mfecane Aftermath: Reconstructive Debates in Southern Africa. Johannesburg: Witwatersrand University Press. 
Hughes, A.J.B. 1956. Caste and Nation among the Rhodesian Ndebele. Manchester: Manchester University Press.

Keppel-Jones, Arthur 1983. Rhodes and Rhodesia: The White Conquest of Zimbabwe, 18841902. Kingston \& Montreal: McGill-Queen’s University Press.

Kinsman, Margaret 1995. Hungry Wolves: The Impact of Violence on Rolong Life, 1823-1836, in Hamilton 1995, 368-394.

Lindgren, Bjorn 2002a. The Politics of Ndebele Ethnicity: Origins, Nationality, and Gender in Southern Zimbabwe. Unpublished Ph.D. thesis, Uppsala University.

Lindgren, Bjorn 2002b. Power, Education, and Identity in Post-Colonial Zimbabwe: Representations of the Fate of King Lobengula of Matabeleland. African Sociological Review 1 (5).

Lindgren, Bjorn 2004 The Internal Dynamics of Ethnicity: Clan Names, Origins and Caste in Southern Zimbabwe, in <http://www.beepmedia.com/pubs/Africa/2004/03/22/1419138>

Lindgren, Bjorn 2005. The Politics of Identity and the Remembrance of Violence: Ethnicity and Gender at the Installation of a Female Chief in Zimbabwe, in Broch-Due, V. (ed), Violence and Belonging: The Quest for Identity in Post-Colonial Africa. London \& New York: Routledge.

Mabhena, Hon. W. H. 2007. Re: The Question of Matabeleland. Letter, 30 May 2007.

Mabhena, Ndaba 2006. The Tribal Warlords that Rule Zimbabwe. Available at $<$ http://www. newzimbabwe.com/pages/opinion64.12515.html>

Moyo, Khanyisela 2006. Ndebeles, A Minority that Needs Protection. Available at $<\mathrm{http}$ ://www. newzimbabwe.com/pages/gukgenocide16.13763.html>

Msindo, Enocent 2004. Ethnicity in Matabeleland, Zimbabwe: A Study of Kalanga-Ndebele Relations, 1860s-1980s. Unpublished Ph.D. thesis, University of Cambridge.

Msindo, Enocent 2006. Ethnicity, not Class? The 1929 Bulawayo Faction Fights Reconsidered. Journal of Southern African Studies 32 (3).

Mthwakazi (2006). Zimbabwe: A Project for the Humiliation of Nkomo. Available at $<$ http:// www.mthwakazionline.org/nkomo2.asp>

Ndhlovu, Finex 2006. The Role of Discourse in Identity Formation and the Manufacture of Ethnic Minorities in Zimbabwe. Paper presented at the Discourse: Constructing Society and Text, Second Symposium on Discourse Analysis organised by the Hispanic Studies Program, Monash University, 10 Nov 2006.

Ndlovu-Gatsheni, Sabelo J. 2003. The Post-Colonial State and Matabeleland: Regional Perceptions of Civil Military Relations, 1980-2002, in Williams, R., Cawthra, G. \& Abrahams, D. (eds), Ourselves to Know: Civil-Military Relations and Defence Transformation in Southern Africa. Pretoria: Institute for Security Studies.

Ndlovu-Gatsheni, Sabelo J. 2004. The Dynamics of Democracy and Human Rights among the Ndebele of Zimbabwe. Unpublished Ph.D. thesis, University of Zimbabwe. 
Ndlovu-Gatsheni, Sabelo J. 2007. Rethinking the Colonial Encounter in Zimbabwe in the Early Twentieth Century. Journal of Southern African Studies 33 (1), 173-191.

Ndlovu-Gatsheni, Sabelo J. 2009. The Ndebele Nation: Reflections on Hegemony, Memory and Historiography. Amsterdam: SAVUSA/Rozenberg Press/UNISA Press.

Nkomo, Joshua 1984. Nkomo: The Story of My Life. London: Methuen.

Nyathi, Pathisa 1994. Igugu LikaMthwakazi: Imbali YamaNdebele, 1820-1893. Gweru: Mambo Press.

Nyathi, Pathisa 1996. Uchuku Olungelandiswe: Imbali YamaNdebele, 1893-1895. Gweru: Mambo Press.

Nyathi, Pathisa 1999. Madoda Lolani Incukuthu: Imbali YamaNdebele, 1896. Gweru: Mambo Press.

Omer-Cooper, John D. 1966. The Zulu Aftermath: Revolution in Bantu Africa. London: Longman.

Pretorius, H.S. \& Kruger, D.W. (eds) 1937. Voorttrekker-Argiefstukke, 1829-1849. Pretoria: Staatsdrukker [Government Printers].

Ranger, Terence 1967. Revolt in Southern Rhodesia, 1896-1897: A Study in African Resistance. London: Heinemann.

Ranger, Terence 1970. The African Voice in Southern Rhodesia, 1898-1930. London: Heinemann.

Ranger, Terence 1985. The Invention of Tribalism in Zimbabwe. Gweru: Mambo Press.

Ranger, Terence 1993. The Invention of Tradition Revisited: The Case of Colonial Africa, in Ranger, T. \& Vaughan, O. (eds), Legitimacy and the State in Twentieth Century Africa. London: Macmillan.

Ranger, Terence 1994a. African Identities: Ethnicity, Nationality and History: The Case of Matabeleland, 1893-1993, in Heidrich, J. (ed), Changing Identities: The Transformation of Asian and African Societies Under Colonialism. Berlin: Das Arabische Buch Verlag.

Ranger, Terence 1994b. The Tribalisation of Africa and the Retribalisation of Europe. St Antony's Seminar Series: Tribe, State, Nation. Oxford: University of Oxford.

Ranger, Terence 1999. Voices from the Rocks: Nature, Culture and History in the Matopos Hills of Zimbabwe. Harare: Baobab.

Roberts, Ray S. 1984. Nguboyenja Lobengula, Unpublished Henderson Paper, University of Zimbabwe.

Roberts, Ray S. 2005. Traditional Paramountcy and Modern Politics in Matabeleland: The End of the Lobengula Royal Family—and of Ndebele Particularism? Heritage of Zimbabwe No. 24, 4-38.

Sibanda, Eliakim 2005. Zimbabwe African People's Union, 1961-1987: A History of Political Insurgency in Southern Rhodesia. Asmara: African World Press. 
Sithole, Masipula 1986. The General Elections, 1979-1985, in Mandaza, Ibbo (ed), Zimbabwe: The Political Economy of Transition, 1980-1986. Dakar: CODESRIA.

Sithole, Masipula 1995. Ethnicity and Democratization in Zimbabwe: From Confrontation to Accommodation, in Glickman, Harvey (ed), Ethnic Conflict and Democratization in Africa. Atlanta: The African Studies Association.

Sithole, Masipula 1999. Zimbabwe: Struggles within the Struggle: Second Edition Harare: Rujeko Publishers.

Tylden, G. 1953. Vegkop, 2 October 1836: Analysis. Africana Notes and News 10 (4).

Vail, L. (ed) 1989. The Creation of Tribalism in Southern Africa. Berkeley: University of California Press.

Yap, Rohjolainen 2001. Uprooting the Weeds: Power, Ethnicity and Violence in the Matabeleland Conflict, 1980-1987. Unpublished Ph.D. thesis, University of Amsterdam. 